\title{
Mycology quality assessment: United Kingdom national scheme
}

\author{
S F PERRY, C K CAMPBELL,* J J S SNELL The Division of Microbiological Reagents and Quality \\ Control, and the *Mycological Reference Laboratory, Central Public Health Laboratory, Colindale, London
}

SUMMARY A mycology quality assessment scheme introduced in 1986 was assessed: 289 laboratories participated in the scheme, and six distributions, each containing four specimens, were made. Levels of performance varied considerably among participating laboratories: performance was highest with the commoner organisms distributed, but some laboratories, encouragingly, achieved a consistently high level of species identification. A questionnaire distributed to participants showed that a wide range of methods are commonly used, some of which are contrary to good practice. As the scheme continues, selection of organisms considered to be relevant and of use to participants will become difficult.

The United Kingdom National External Quality Assessment Scheme for Microbiology (UK NEQAS) has been described previously. ${ }^{12}$ As part of this scheme simulated specimens are prepared in the organising laboratory (Division of Microbiological Reagents and Quality Control (DMRQC)) and despatched to participants, who examine these specimens and report their results to the DMRQC. The scheme has expanded to cover many areas of microbiology, but finite resources and unlimited potential have inevitably led to the neglect of external quality assessment in some areas of microbiology including mycology. Since 1986, cooperation between the DMRQC and the Public Health Laboratory Service Mycological Reference Laboratory at Colindale (MRL) has resulted in the introduction of a mycology quality assessment scheme as a service to the many laboratories performing diagnostic mycology.

\section{Material and methods}

A total of 289 laboratories currently participate in the mycology section of the scheme, of which 250 are in the United Kingdom and 39 are overseas. Details of methods used by participants were ascertained by means of a questionnaire sent with the first distribution of specimens.

The simulated specimens, which consisted of freeze dried cultures of fungi, were mostly pure cultures. These specimens were designed to assess proficiency in

Accepted for publication 1 December 1988 identification and should not have presented difficulties in isolation. A few mixtures of fungi and nonpathogenic bacteria were distributed to test proficiency in both isolation and identification. The fungi distributed were chosen from those most commonly isolated in the United Kingdom (table 1).

Viability of the strains and retention of characteristic properties was checked by repeated examination of

Table 1 Species of fungi isolated by clinical laboratories and reported to the Communicable Disease Surveillance Centre for the year 1986

\begin{tabular}{lrl} 
& Total No & Individual report \\
of reports & as per cent total \\
\hline Aspanism & 21 & $0 \cdot 4$ \\
Aspergillus niger & 16 & $0 \cdot 3$ \\
Aspergillus flavus & 5 & $0 \cdot 1$ \\
Aspergillus sp & 8 & $0 \cdot 2$ \\
Candida albicans & 316 & $6 \cdot 6$ \\
Candida parapsilosis & 27 & $0 \cdot 6$ \\
Candida sp & 57 & $1 \cdot 2$ \\
Torulopsis glabrata & 15 & $0 \cdot 3$ \\
Cryptococcus neoformans & 10 & $0 \cdot 2$ \\
Cryptococcus sp & 1 & $0 \cdot 02$ \\
Epidermophyton floccosum & 227 & $4 \cdot 7$ \\
Malassezia furfur & 366 & $7 \cdot 6$ \\
Microsporum canis & 347 & $7 \cdot 2$ \\
Microsporum audouinii & 7 & $0 \cdot 1$ \\
Microsporum gypseum & 7 & $0 \cdot 1$ \\
Microsporum persicolor & 3 & $0 \cdot 1$ \\
Trichophyton rubrum & 2155 & $45 \cdot 0$ \\
Trichophyton mentagrophytes & 899 & $18 \cdot 7$ \\
Trichophyton verrucosum & 251 & $5 \cdot 2$ \\
Trichophyton tonsurans & 29 & $0 \cdot 6$ \\
Trichophyton violaceum & 24 & $0 \cdot 5$ \\
Trichophyton soudanense & 15 & $0 \cdot 3$ \\
Trichophyton erinacei & 4 & $0 \cdot 1$ \\
Trichophyton schoenleinii & 2 & $0 \cdot 04$ \\
& & \\
\hline & & \\
\hline
\end{tabular}


samples before, during and after each distribution period, including samples subjected to two journeys through the post. All strains of fungi used in the scheme were obtained from the MRL. Six distributions, each comprising four specimens, were sent (table 2).

The scoring scheme used to assess results was the same in principle as that used in other schemes. ${ }^{3}$ In general, scores of 2 were allocated for correct results, 1 for partially correct results, such as inadequate levels of identification, 0 for wrong results, and -1 was reserved for the reporting of unexpected pathogens.

\section{Results}

\section{QUESTIONNAIRE FINDINGS}

The results from 193 returned questionnaires were analysed. Not all laboratories answered all the questions and so the total numbers using various methods do not necessarily add up to 193 .

\section{Media used for primary isolation}

Many different media were used for primary isolation of fungi from skin specimens. Most could be classified as variants of Sabouraud's agar (used by 284 laboratories), malt agar (37 laboratories), and dermatophyte test medium (48 laboratories). Other media were used by only a small number of laboratories. Of the 189 laboratories that replied to questions concerning presence or absence of antibiotics in the media, 165 laboratories were using media containing the antifungal agent cycloheximide. Of these, 43 laboratories used only media containing cycloheximide and 122 used both media containing cycloheximide together with media not containing this additive.

\section{Media used for examination of yeast morphology} Cornmeal or rice agar was used by 56 laboratories, 51 of which incubated at or below $30^{\circ} \mathrm{C}$ and three at $37^{\circ} \mathrm{C}$. Cornmeal or rice agar was not used by 130 laboratories.

Table 2 Organisms distributed

\begin{tabular}{ll}
\hline Acremonium species & Microsporum canis \\
Aspergillus flavus & Microsporum gypseum \\
Aspergillus fumigatus & Mucor species $\dagger$ \\
Aspergillus nidulans $\dagger$ & Nocardia asteroides $\ddagger$ \\
Candida albicans & Nocardia otitidis-caviarum $\ddagger$ \\
Candida krusei & Scopulariopsis brevicaulis \\
Candida parapsilosis* & Trichophyton mentagrophytes* \\
Candida tropicalis & Trichophyton rubrum* \\
Cladosporium species $\dagger$ & Trichophyton tonsurans \\
Cryptococcus neoformans & Trichophyton beigelii \\
Epidermophyton floccosum & \\
\hline *Two specimens containing different strains distributed. \\
†Specimens designated as negative (ie no unequivocal pathogens). \\
†Actinomycetes are included as these are commonly examined by \\
mycologists.
\end{tabular}

Use of the germ tube test to identify Candida albicans The germ tube test was used by 173 laboratories and 18 did not perform this test. Incubation temperatures of $35-37^{\circ} \mathrm{C}$ were used by 169 laboratories and four used temperatures of $28-30^{\circ} \mathrm{C}$. Ten laboratories incubated the germ tube test for less than two hours, 152 for between two and four hours, and nine for longer than four hours.

\section{Identification of aerobic actinomycetes}

The questionnaire indicated a wide range of practices for the identification of actinomycetes. Only 19 of 193 reports mentioned hydrolysis of casein, xanthine, and tyrosine, the "traditional" methods by which Nocardia asteroides may be distinguished from most other actinomycetes.

\section{PARTICIPANTS' RESULTS IN SPECIMENS DISTRIBUTED}

The percentages of laboratories obtaining fully correct results with specimens containing pathogens are shown in tables 3-5. Laboratories were designated as fully correct either because of identification to species level or incomplete identification with referral of the isolate to a reference laboratory.

\section{Dermatophytes}

Participants' results (table 3) indicate variable levels of performance with the dermatophytes that were distributed. Trichophyton rubrum, the commonest dermatophyte, was identified by $75 \%$ and $71 \%$ of the laboratories, respectively, in two distributions. Similar success rates were seen with the less common but familiar $T$ mentagrophytes, Epidermophyton floccosum, and Microsporum canis. The lower success rate of $44 \%$ for identification of $T$ tonsurans possibly reflects the rarity of isolation of this organism in the United Kingdom (less than $1 \%$ of all dermatophytes,

Table 3 Percentage of laboratories with fully correct results in specimens containing dermatophyte fung $i$

\begin{tabular}{|c|c|c|c|}
\hline \multirow[b]{2}{*}{ Organisms } & \multicolumn{3}{|c|}{$\begin{array}{l}\text { Percentage of laboratories judged as fully } \\
\text { correct because of: }\end{array}$} \\
\hline & $\begin{array}{l}\text { A } \\
\text { Identification } \\
\text { to } \\
\text { species level }\end{array}$ & $\begin{array}{l}\text { B } \\
\text { Incomplete } \\
\text { identification } \\
\text { with referral }\end{array}$ & $\begin{array}{l}A+B \\
\text { Acceptable } \\
\text { identification } \\
\text { or referral }\end{array}$ \\
\hline $\begin{array}{l}\text { Trichophyton ment- } \\
\text { agrophytes }\end{array}$ & $83,79^{*}$ & 7,6 & 91,85 \\
\hline $\begin{array}{l}\text { Trichophyton ton- } \\
\text { surans }\end{array}$ & 44 & 15 & 59 \\
\hline $\begin{array}{l}\text { Trichophyton rubrum } 7 \\
\text { Epidermophyton floc- } 7 \\
\text { cosum }\end{array}$ & $\begin{array}{l}75,71^{*} \\
75\end{array}$ & 13,4 & $\begin{array}{l}88,75 \\
77\end{array}$ \\
\hline $\begin{array}{l}\text { Microsporum canis } 7 \\
\text { Microsporum gypseum? }\end{array}$ & $\begin{array}{r}73 \\
79\end{array}$ & $\begin{array}{l}6 \\
6\end{array}$ & $\begin{array}{l}79 \\
85\end{array}$ \\
\hline
\end{tabular}


table 1). Many of the errors in this case arose over confusion with $T$ mentagrophytes.

\section{Yeasts}

The Candida albicans and Cryptococcus neoformans were identified by $93 \%$ and $91 \%$ of participants, respectively (table 4). These high success rates probably reflect the ease by which $C$ albicans can be identified by the germ tube test and an awareness of the clinically important $C$ neoformans. Success rates for other yeasts distributed were lower with many laboratories reporting organisms giving a negative result in the germ tube test as "yeast isolated not $C$ albicans".

\section{Miscellaneous organisms}

Overall, laboratories had few problems with isolating the fungi, but identification to species level was less successful (table 5). Few laboratories seemed to be confident about the identification of Nocardia species, but only $70 \%$ would have referred them to a specialist laboratory. Of the mould pathogens distributed, only Aspergillus fumigatus was identified by $82 \%$ of laboratories. The often doubtful role of Acremonium species in infection probably contributed to the low rate of reporting, but undoubtedly the wet, yeast-like growth of the strain used misled many participants into treating it as a yeast. The true growth form of this organism can be seen by studying its morphology on cornmeal or rice agar, a test shown by the questionnaire on methods to be omitted by many laboratories from the set of tests used for yeast identification.

\section{Negative strains}

Table 6 shows results obtained with negative specimens - that is, those containing no unequivocal pathogens. As with other distribution types, ${ }^{3}$ pathogens were reported from specimens which contained only commensals. Only a few of these reports could be

Table 4 Percentage of laboratories with fully correct results in specimens containing yeast

\begin{tabular}{|c|c|c|c|}
\hline \multirow[b]{2}{*}{ Organisms } & \multicolumn{3}{|c|}{$\begin{array}{l}\text { Percentage of laboratories judged as fully } \\
\text { correct because of: }\end{array}$} \\
\hline & $\begin{array}{l}\text { A } \\
\text { Identification } \\
\text { to } \\
\text { species level }\end{array}$ & $\begin{array}{l}\text { B } \\
\text { Incomplete } \\
\text { identification } \\
\text { with referral }\end{array}$ & $\begin{array}{l}A+B \\
\text { Acceptable } \\
\text { identification } \\
\text { or referral }\end{array}$ \\
\hline $\begin{array}{l}\text { Candida albicans } \\
\text { Candida parapsilosis } \\
\text { Candida tropicalis } \\
\text { Candida krusei } \\
\text { Cryptococcus neofor- } \\
\text { mans }\end{array}$ & $\begin{array}{l}93 \\
58,66^{*} \\
31 \\
46 \\
91\end{array}$ & $\begin{array}{r}5 \\
15 \\
38 \\
32 \\
6\end{array}$ & $\begin{array}{l}98 \\
73,76 \\
69 \\
78 \\
97\end{array}$ \\
\hline Trichosporon beigelii & 50 & 33 & 83 \\
\hline
\end{tabular}

*Two specimens containing different strains were distributed.
Table 5 Percentage of laboratories with fully correct results in specimens containing miscellaneous organisms

\begin{tabular}{|c|c|c|c|}
\hline \multirow[b]{2}{*}{ Organisms } & \multicolumn{3}{|c|}{$\begin{array}{l}\text { Percentage of laboratories judged as fully } \\
\text { correct because of: }\end{array}$} \\
\hline & $\begin{array}{l}\text { A } \\
\text { Identification } \\
\text { to } \\
\text { species level }\end{array}$ & $\begin{array}{l}\text { B } \\
\text { Incomplete } \\
\text { identification } \\
\text { with referral }\end{array}$ & $\begin{array}{l}A+B \\
\text { Acceptable } \\
\text { identification } \\
\text { or referral }\end{array}$ \\
\hline $\begin{array}{l}\text { Nocardia otitidis- } \\
\text { caviarum }\end{array}$ & 11 & NA & $11^{*}$ \\
\hline $\begin{array}{l}\text { Nocardia asteroides } \\
\text { Aspergillus fumigatus } \\
\text { Aspergillus flavus } \\
\text { Scopulariopsis } \\
\text { brevicaulis }\end{array}$ & $\begin{array}{l}23 \\
82 \\
56 \\
42\end{array}$ & $\begin{array}{r}54 \\
11 \\
12 \\
9\end{array}$ & $\begin{array}{l}77 \\
93 \\
68 \\
51\end{array}$ \\
\hline Acremonium sp & 12 & 23 & 35 \\
\hline
\end{tabular}

*The low percentage of laboratories achieving full marks with this specimen reflects the use of an over rigorous scoring scheme which has since been modified.

explained by the transposition of quality assessment specimens or results in the recipient laboratory.

\section{Cumulative laboratory performance}

The distribution of cumulative scores achieved by laboratories examining all 23 specimens is shown in table 7. Although the average cumulative score of 37 $(80 \%$ of a possible total of 46$)$ for the series is not high, $51(40 \%)$ laboratories achieved $90 \%$ or greater of their total possible scores.

\section{Discussion}

The standard of performance with these specimens varied and was generally highest with the commoner organisms distributed. It is difficult, both to decide which organisms should be distributed, and to set a level of acceptable identification, as many laboratories

Table 6 Percentage of laboratories recording pathogens in successive negative specimens

\begin{tabular}{lll}
\hline $\begin{array}{l}\text { Organisms designated } \\
\text { as non-pathogenic }\end{array}$ & $\begin{array}{l}\text { Per cent of } \\
\text { laboratories } \\
\text { recording pathogens }\end{array}$ & $\begin{array}{l}\text { Principal } \\
\text { pathogens } \\
\text { recorded }\end{array}$ \\
\hline Cladosporium sp & 4 & $\begin{array}{l}\text { Trichophyton ment- } \\
\text { agrophytes } \\
\text { Trichophyton rubrum } \\
\text { Microsporum canis } \\
\text { Microsporum } \\
\text { audouinii } \\
\text { Phialophora sp } \\
\text { Phialophora jeansel- } \\
\text { mei }\end{array}$ \\
& & $\begin{array}{l}\text { Sporotrichum schen- } \\
\text { ckii } \\
\text { Trichophyton sp } \\
\text { Trichophyton ment- } \\
\text { agrophytes } \\
\text { Phialophora } \text { sp } \\
\text { Trichophyton ment- } \\
\text { agrophytes }\end{array}$ \\
\hline
\end{tabular}


Table 7 Distribution of cumulative scores

\begin{tabular}{|c|c|c|c|c|c|c|c|c|c|c|}
\hline Per cent of total possible score & $100-95$ & $94-88$ & $87-82$ & $81-75$ & $74-69$ & $68-62$ & $61-56$ & $55-50$ & $49-42$ & 41 \\
\hline $\begin{array}{l}\text { No of achieving laboratories } \\
\text { Cumulative per cent of laboratories } \\
\text { achieving }\end{array}$ & 19 & $\begin{array}{l}51 \\
40\end{array}$ & $\begin{array}{l}34 \\
59 \cdot 4\end{array}$ & $\begin{array}{l}28 \\
75 \cdot 4\end{array}$ & $\begin{array}{l}21 \\
87 \cdot 4\end{array}$ & $\begin{array}{l}10 \\
93 \cdot 1\end{array}$ & $\stackrel{6}{96 \cdot 6}$ & $\begin{array}{c}1 \\
97 \cdot 1\end{array}$ & $\begin{array}{c}1 \\
97 \cdot 7\end{array}$ & $\begin{array}{r}4 \\
100\end{array}$ \\
\hline
\end{tabular}

Cumulative scores are shown for the 175 laboratories that returned reports on all 23 specimens, a total score of 46 being possible. Specimen 1566 ( $N$ otitidis-caviarum) was omitted from the calculations as the over-rigorous scoring of this specimen influenced the cumulative performances.

would normally examine only a limited range of specimens and make extensive use of referral facilities. As with all quality assessment schemes, it is necessary to balance the stimulatory effect of providing educational specimens against the need to allow laboratories to assess their basic capabilities with medically important and commonly encountered organisms. Thus although examination of pathogenic fungi rarely if ever encountered in the United Kingdom such as Paracoccidioides brasilensis and Trichophyton concentricum is a useful exercise for participants, the inclusion of such specimens is at the expense of those containing commoner organisms which must form the basis for assessment of performance. Even with pathogens indigenous to the United Kingdom, many species of fungus are uncommon.

In 1986 isolations of 26 different species of fungus were reported to the Communicable Disease Surveillance Centre (CDSC) (unpublished observations). Only seven species accounted for $95 \%$ of all fungi reported, however, and $45 \%$ were of only one species. Therefore, as the scheme continues selection of organisms considered to be relevant and of use to participants will become difficult. At present, participants' reports of incomplete identification are regarded as fully correct if accompanied by the stated intention to refer the isolate. Thus laboratories reporting Trichophyton sp or an unnamed dermatophyte isolated from a specimen containing $T$ rubrum would be judged as fully correct. In future, complete identification may be required to score full marks in distributions of organisms considered to be easily identifiable by a routine laboratory-for example, $T$ mentagrophytes.

The wide variety of methods and media used by participants reflects the lack of standardisation in microbiology noted in other distribution types. ${ }^{4}$ Association between the use of various methods and success in quality assessment specimens is difficult to show from analysis of results from these distributions as specimens were designed to assess the quality of laboratory performance rather than differences between methods. Some of the methods used, however, are contrary to good practice. Laboratories that depend solely on cycloheximide-free media are presumably encountering many contaminating moulds which are always present on skin. Conversely, laboratories using only media containing cycloheximide may not isolate the non-dermatophyte mould pathogens. Laboratories using neither cornmeal nor rice agar to examine yeast morphology will lack the additional morphological information which even commercial kits often require for adequate identification.

Some of the laboratories using either of these media reported the use of incubation temperatures above $30^{\circ} \mathrm{C}$. The accepted temperature of incubation is between $25-30^{\circ} \mathrm{C}$, and incubating at temperatures above this may lead to spurious results. Failure to use the germ tube test in the identification of yeasts is surprising in view of the simplicity and reliability of this test. There was great variation in times of incubation with periods of up to three days recorded. At $37^{\circ} \mathrm{C}$ incubation periods of less than two hours or greater than four hours increase the chance of false negative and positive results, respectively. Outside of this time range and below $31^{\circ} \mathrm{C}$ some strains of $C$ albicans may not produce germ tubes. ${ }^{5}$

Few laboratories used hydrolysis of casein, xanthine, and tyrosine in the identification of actinomycetes. If laboratories report $N$ asteroides on the basis of morphology and acid fastness alone other species of Nocardia may be overlooked.

When designing quality assessment specimens it is important to produce a realistic finished product. Many of the fungi used do not readily emulsify, making it difficult to ensure an homogenous suspension of organisms prior to dispensing and freeze drying. Therefore, to ensure that all phials contain viable material, specimens have to be made with unrealistically heavy numbers of organisms and do not provide uniformly stringent tests of culture media and technique. A further problem encountered with specimen preparation is the phenomenon of "pleomorphism" in which repeated subculture of dermatophytes may result in cultures becoming nonsporing and losing features such as typical pigmentation and topography, which renders them impossible to identify.

Results with species of fungi so far distributed in the UK NEQAS have shown what is probably an acceptable success rate for identification of several of the common fungal pathogens, and also highlighted areas where more expertise would be desirable. The fact that 
some laboratories consistently score well may reflect the differences in the size and capabilities of laboratories, but is nevertheless reassuring in showing that high standards are obtainable. In future distributions it is hoped to meet the more demanding challenge of assessing the results of direct examination of specimens such as skin scrapings and biopsy material.

\section{References}

1 Snell JJS, deMello JV, Gardner PS. The United Kingdom national microbiological quality assessment scheme. J Clin Pathol 1982;35:82-93.

2 Snell JJS. United Kingdom national external microbiological quality assessment scheme for microbiology. Eur $J$ Clin
Microbiol 1985;4:464-7.

3 Snell JJS, deMello JV, Phua TJ. Errors in bacteriological techniques: results from the United Kingdom national external quality assessment scheme for microbiology. Med Lab Sci 1986;43:344-55.

4 Snell JJS, George RC, Perry SF, Erdman YJ. Antimicrobial susceptibility testing of Streptococcus pneumoniae: quality assessment results. J Clin Pathol 1988;41:384-7.

5 Mackenzie DWR. Serum tube identification of Candida albicans. J Clin Pathol 1962;15:563-5.

Requests for reprints to: Mr S F Perry, Central Public Health Laboratory, Division of Microbiological Reagents and Quality Control, 61 Colindale Avenue, London NW9 5HT, England. 